Al-Fikra: Jurnal Ilmiah Keislaman, Vol. 5, No. 1, Januari-Juni 2006

\title{
KEBIJAKAN PEMERINTAH TENTANG YAYASAN DAN EKSISTENSI MADRASAH SWASTA DI INDONESIA (Antara Solusi dan Permasalahannya)
}

\author{
Muhammad Syaifudin \\ Fakultas Tarbiyah dan Keguruan UIN Suska Riau, Pekanbaru
}

\begin{abstract}
The Government Policy on Foundations and the Existence of Private Religious Schools in Indonesia: The establishment of religious schools is the participation of the community in achieving the goal of the nation that is to develop the mentality people. Therefore, the government supports the establishment of foundations where the community are concerned with the education of people. So far, the support obtained is just in the form of non-material things because private religious schools are much dependent on the foundations under which they exist. The government support to the foundations that are developing very steadily can be seen from its policy through the Acts number 16 the year 2000 on Foundations. The impact felt by the community with the birth of this policy is that the legal status of the foundations is clear in the national constitutions so that they can run their programs smoothly. In addition, the role of the community, in this respect, the builders of the foundations is limited so that the owners may not run them as they wishe. On the other hand, the impacts of the Acts on Foundations towards the religious schools which operate under their umbrellas are progression in various aspects. For example, the foundations are more proportional in giving the rights of the schools which have so far been dominated by the owners especially in financial matters. But one of the negative impacts of the Acts on the part of the owners of the foundations is that the owners do not manage the educational programs seriously which may affect the progress of the foundations.
\end{abstract}

Keywords: Religious Schools, Education, Educational Programs.

\section{Pendahuluan}

Kesan apakah yang pertama kali muncul ketika mendengar istilah madrasah swasta? Seorang teman, yang kebetulan almuni fakultas Tarbiyah IAIN, mengatakan bahwa madrasah swasta hampir identik dengan "keterbelakangan". Teman lain bahkan mengatakan, "madrasah swasta itu bisa jalan saja sudah untung". Kebanyakan madrasah swasta memang berlokasi di pedesaan. Fasilitas dan guru yang dimiliki pun seadanya. Meskipun demikian, benarkah kesan teman tersebut?

Sejarah madrasah swasta adalah sejarah panjang kaum Muslim Indonesia dalam turut serta mencerdaskan kehidupan bangsa. Eksistensi lembaga ini memang tidak bisa dipisahkan dari kesadaran masyarakat Muslim akan pentingnya pendidikan; dari mulai inisiatif pendiriannya, tanah dan bangunan, fasilitas sampai tenaga guru, semuanya dilakukan oleh masyarakat secara 
swadaya -baik oleh organisasi-organisasi sosial-keagamaan maupun yayasanyayasan pendidikan Islam. ${ }^{1}$ Kondisi seperti ini pada gilirannya, memunculkan lembaga pendidikan yang beraneka ragam, tidak saja dari jenis tetapi juga kualitasnya.

Oleh karena itu, menolak atau mengakui sepenuhnya kebenaran kesan tersebut jelas tidak mungkin. Kondisi obyektif sebagian madrasah swasta memang masih terbelakang tetapi bukan berarti tidak ada madrasah swasta yang maju. Beberapa madrasah swasta yang maju bahkan lebih diminati masyarakat daripada madrasah negeri atau sekolah umum negeri. Dengan demikian, madrasah swasta mengandung potensi yang besar untuk maju dan berdiri sejajar-jika tidak malah melampaui-madrasah negeri atau sekolah umum negeri.

Keberadaan madrasah ${ }^{2}$ swasta $^{3}$ tidak dapat dilepaskan dari adanya yayasan atau lembaga organisasi yang menaunginya, karena kebijakan

${ }^{1}$ Banyak teori yang menekankan tentang pentingnya hubungan antara pemerintah, lembaga, professional, dan masyarakat secara umum. Semua itu berwujud dalam bentuk pertisipasi masyarakat, yaitu hubungan antara orang tua dengan sekolah. Lihat Carol Vincent, Parents and Teachers Power and Participation, (London: Falmer Press, 1996), hlm. 8. Masyarakat berperan dalam menetapkan dasar-dasar pengajaran ilmu pengetahuan baik kemajuannya maupun kemundurannya. Selain itu juga masyarakat berperan mempersiapkan aspek-aspek material (sumber dana) maupun non-material (sumber daya manusia) yang melaksanakan tanggungjawab pengajaran. Lihat Ibrahim Basuni Emira, Tadris al-Ulum wa al-Tarbiyah alIlmiyyah, (Mesir: Dar al-Ma’arif, 1979), hlm.18.

2Kata "madrasab" dalam bahasa Arab adalah bentuk kata "keterangan tempat" (₹haraf makan) dari akar kata "darasa". Secara harfiah "madrasab" diartikan sebagai tempat belajar para pelajar", atau "tempat untuk memberikan pelajaran. Lihat Mehdi Nakosteen, Kontribusi Islam atas Dunia Intelektual Barat: Deskripsi Analisis Abad Keemasan Islam, Edisi Indonesia (Surabaya: Risalah Gusti, 1996), hlm. 66. Dari akar kata "darasa" juga bisa diturunkan kata "midras" yang mempunyai arti "buku yang dipelajari" atau tempat belajar"; kata "al-midras" juga diartikan sebagai rumah untuk mempelajari kitab Taurat". Lihat Abu Luwis al-Yasu'i, al-Munjid Fi alLughah Wa al-Munjid Fi al-A'lam, Cet-23 (Beirut: Dar al-Masyriq, tt), hlm. 221. Sebenarnya istilah "madrasah" ini sudah pernah dikenal pada awal-awal Islam. Hanya saja, bukan dalam arti lembaga formal dengan pembagian kelas dan kurikulum seperti sekarang ini, melainkan dalam arti sekedar tempat memberikan pelajaran dalam bentuk halaqah atau kelompok belajar yang mengambil tempat di sebahagian ruangan masjid. Lihat Zuharaini, dkk., Sejarah Pendidikan Islam, Cet.II, (Jakarta: Dirjen Binbaga Islam Depag RI, 1986), hlm. 71.

${ }^{3}$ Menurut penulis, dalam konteks lembaga pendidikan, istilah swasta adalah lawan dari kata negeri. Madrasah swasta adalah lembaga pendidikan yang didirikan berdasarkan inisiatif dan swadaya masyarakat yang memiliki kepedulian terhadap pendidikan. Sedangkan madrasah negeri adalah lembaga pendidikan yang didirikan oleh pemerintah. Mengenai pendirian madrasah swasta didasarkan atas SK.Menteri Agama No. 5 Tahun 1977 yang pendirian pelaksanaannya dituangkan ke dalam Surat Keputusan Direktur Jenderal Bimbingan Masyarakat Islam No. Kep/D/69/77. Dalam hubungan ini, madrasah swasta diartikan sebagai lembaga pendidikan yang menjadikan mata pelajaran agama Islam sebagai mata pelajaran dasar yang diberikan sekurang-kurangnya $30 \%$ di samping mata pelajaran umum, dan diselenggarakan oleh organisasi, yayasan, badan atau perorangan sebagai pengurus atau pemiliknya. Abdul Rachman Shaleh, Madrasah dan Pendidikan Anak Bangsa: Visi, Misi dan Aksi, (Jakarta: Raja Grafindo Persada, 2004), hlm. 30. 
pemerintah mengharuskan adanya yayasan yang menaungi madrasah atau sekolah yang didirikan secara swadaya oleh masyarakat. Berdirinya madrasah swasta merupakan bentuk partisipasi masyarakat dalam mewujudkan tujuan nasional yaitu mencerdaskan kehidupan bangsa. Hal ini disebabkan pemerintah memiliki keterbatasan dalam mendirikan dan mengelola lembaga pendidikan. Dengan kata lain bahwa pemerintah hanya mampu mendirikan sekolah atau madrasah yang berstatus negeri. Oleh karena itu, pemerintah mendukung berdirinya yayasan yang merupakan kumpulan dari masyarakat yang memiliki kepedulian terhadap pendidikan anak bangsa, walaupun dukungan itu baru bersifat non materil karena secara materil madrasah swasta sangat bergantung dengan yayasan yang menaunginya. Dukungan pemerintah terhadap yayasan yang berkembang dengan pesat tersebut dapat dilihat dari kebijakan pemerintah melahirkan Undang-undang Nomor 16 tahun 2001 tentang Yayasan.

Dari kenyataan di atas, akan muncul berbagai pertanyaan yang memerlukan jawaban antara lain: Apakah dengan lahirnya UU tentang yayasan tersebut, peran masyarakat dalam hal ini Yayasan menjadi semakin terbatas? Bagaimana dampak dari UU tersebut terhadap madrasah swasta yang bernaung di bawah Yayasan?

Pertanyaan-pertanyaan tersebut tidak mungkin terjawab secara utuh dalam tulisan yang sederhana ini. Untuk menjawabnya, tentu saja memerlukan penelitian ilmiah. Oleh karena itu, makalah ini akan membahas kebijakan pemerintah tentang tentang Yayasan seperti yang termaktub dalam Undangundang Republik Indonesia No. 16 Tahun 2001 (antara solusi dan permasalahannya) dan dampak berlakunya UU tersebut terhadap keberadaan madrasah swasta yang berada di bawah Yayasan yang ada di Indonesia.

\section{Kebijakan Pemerintah Tentang Yayasan (antara Solusi dan Permasalahan)}

Reformasi ${ }^{4}$ sebagai suatu gerakan nasional telah mengubah kebijakan pembangunan masa lampau menjadi lebih demokratis, mengakui persamaan derajat manusia, pembangunan yang lebih terdesentralisasi dalam rangka menuju masyarakat madani. ${ }^{5}$ Reformasi politik pendidikan nasional merupakan

${ }^{4} \mathrm{Hal}$ yang paling diprioritaskan dalam proses reformasi adalah: (1) Pelaksanaan otonomi daerah; (2) Akuntabilitas sekolah, terutama terkait dengan standar pembelajaran siswa; dan (3) Eksistensi kurikulum dan standar yang diterapkan untuk memasuki semua sekolah. Lihat Brian J. Caldwell and Don K. Hayward, The Future of Schools; Lesson From The Reform of Public Education, (London: Falmer Press, 1998), hlm. 47.

${ }^{5}$ Konsep masyarakat madani, secara semantic, merupakan terjemahan dari kata almujtama' al-madani dengan derivasi kata madinah yang berarti masyarakat kota. Di sisi lain, madani berasal dari kata tamaddun dan madaniyah yang bermakna peradaban. Dengan demikian, masyarakat madani identik dengan masyarakat kota yang beradab. Profil mayarakat tersebut mengacu pada struktur masyarakat yang dikembangkan oleh Nabi Muhammad saw ketika menata masyarakat Madinah. Bila dicermati lebih lanjut format penataan masyarakat 
keniscayaan sejarah yang harus didukung oleh semua pihak agar mencapai citacita education for all secara adil dan berkelanjutan. ${ }^{6}$ Salah satu bentuk nyata dari reformasi pendidikan adalah pelaksanaan otonomi penyelenggaraan pendidikan yang bisa juga disebut dengan desentralisasi pendidikan ${ }^{7}$ yang menekankan pada peningkatan partisipasi masyarakat ${ }^{8}$ dalam kerangka

Madinah yang dilakukan Rasulullah saw, dengan data otentik yang dapat dijadikan rujukan adalah sebuah undang-undang yang disusun Rasulullah berdasarkan kesepakatan seluruh penduduk Madinah dan sekitarnya yang terekam secara eksplisit dalam konstitusi yang dikenal Piagam Madinah. Dalam teks Piagam Madinah, masyarakat yang dibangun Rasulullah jelas memiliki karakter masyarakat heterogen, baik dari segi keturunan, budaya dan agama. Di dalamnya terdapat masyarakat muslim (Muhajirin dan Anshar), kaum Yahudi dan Arab nonMuslim. Lihat Syakirman M. Noor, Menuju Masyarakat Madani Sebuah Pengantar dalam Indonesia Baru Menuju Masyarakat Madani (Padang: Baitul Hikmah Press, 2000), hlm. V.

${ }^{6}$ A. Qodri Azizy, Pengantar dalam Abdul Rachman Shaleh, Madrasah dan Pendidikan Anak Bangsa: Visi, Misi dan Aksi, (Jakarta: Raja Grafindo Persada, 2004), hlm. X.

${ }^{7}$ Desentralisasi pendidikan harus diarahkan pada upaya pemberdayaan masyarakat pada level sekolah dengan tetap berpegang kepada standar minimum kompetensi (basic competencies) yang berlaku secara nasional. Pendekatan penyelenggaraan pendidikan harus diubah dari sentralisasi menjadi desentralisasi yang menekankan kepada peningkatan partisipasi masyarakat. Desentralisasi pendidikan tidak hanya menyangkut pelimpahan wewenang birokrasi dari pusat ke daerah, melainkan juga mencakup otonomi pada tingkat lembaga pendidikan.

${ }^{8}$ Partisipasi yang berlaku di masyarakat kita masih belum diartikan menurut persepsi yang universal. Para perencana pembangunan mengartikan "sebagai dukungan terhadap rencana atau proyek pembangunan yang direncanakan pemerintah dan ditentukan oleh pemerintah. Ukuran partisipasi diukur dengan masyarakat untuk ikut menanggung biaya pembangunan, baik berupa uang maupun tenaga yang diberikan pada pemerintah. Partisipasi yang berlaku universal adalah "kerjasama yang erat antara perencana dan rakyat dalam merencanakan, melaksanakan, melestarikan dan mengembangkan hasil pembanagunan yang telah dicapai. Lihat Nanang Fattah, Konsep Manajemen Berbasis Sekolab (MBS) Dan Dewan Sekolah, (Bandung: Pustaka Bani Quraisy, 2004), hlm. 114. Masyarakat memandang sekolah (lembaga pendidikan) sebagai cara yang meyakinkan dalam membina perkembangan para siswa (dan mahasiswa), karena itu masyarakat berpartisipasi dan setia kepadanya. Namun hal ini tidak otomatis terjadi terutama di negara-negara berkembang termasuk Indonesia. Hal ini disebabkan karena banyak warga masyarakat yang belum paham akan makna lembaga pendidikan, lebih-lebih bila kondisi sosial ekonomi mereka rendah, mereka hampir tidak hirau akan lembaga pendidikan. Pusat perhatian mereka adalah pada kebutuhan dasar kehidupan sehari-hari. Untuk mengikutsertakan warga masyarakat ini dalam pembangunan pendidikan di sekolah/perguruan tinggi, sudah sepatutnya para manajer pendidikan melalui tokoh-tokoh masyarakat aktif menggugah perhatian mereka dengan cara mengundang para tokoh ini untuk membahas kerjasama dalam meningkatkan pendidikan. Di negara-negara maju, terutama yang menganut sistem desentralisasi sekolah, kesadaran masyarakat sebagai pemilik dan penanggung jawab lembaga pendidikan sudah tinggi. Partisipasi mereka sudah besar, baik dalam perencanaan, pelaksanaan, maupun dalam melakukan kontrol. Mereka benar-benar merasa memiliki, sehingga sumbangan moral dan material mereka terhadap lembaga pendidikan begitu besar. Mereka melakukan semua itu karena mereka yakin sekali bahwa pendidikan adalah modal utama bagi peningkatan kehidupan keluarga, masyarakat dan bangsa. Lihat Nanang Fattah, Konsep.., hal. 187. Di Indonesia, walaupun garis-garis besar aktifitas pendidikan beserta metode kerjanya sudah diberikan oleh pemerintah pusat, tidak 
community based education (pendidikan berbasis masyarakat). ${ }^{9}$ Hal demikian akan sejalan dengan konsep manajemen peningkatan mutu pendidikan berbasis sekolah (school based management). ${ }^{10}$ Dengan sistem Manajemen berbasis sekolah ini, diharapkan sekolah akan lebih mandiri dan mampu menentukan arah pengembangan yang sesuai dengan kondisi dan tuntutan lingkungan masyarakatnya.

Menurut penulis, satu-satunya lembaga pendidikan yang dianggap telah melaksanakan konsep di atas adalah lembaga pendidikan swasta. Hal ini dikarenakan lembaga pendidikan swasta hidup dan berkembang secara mandiri dengan bantuan partisipasi masyarakat yang ada di sekitarnya dalam wujud Yayasan ${ }^{11}$ yang merupakan suatu bentuk dari badan hukum, yang pendiriannya pada masa lalu hanya berdasarkan kebiasaan di masyarakat karena memang belum ada peraturan undang-undang yang secara khusus mengatur tentang keberadaan yayasan. Realitas yang terjadi di masyarakat adalah bahwa banyak yayasan yang secara sungguh-sungguh mempunyai niat baik atau tujuan mulia

berarti tidak ada yang perlu difikirkan oleh para manajer pendidikan beserta tokoh-tokoh masyarakat dalam mengembangkan pendidikan. Beberapa bentuk partisipasi masyarakat dalam pendidikan antara lain: Dewan Pendidikan, Komite Sekolah, Persatuan Orang Tua Siswa, dan sebagainya.

${ }^{9}$ Manajemen berbasis masyarakat (community Based Management) memberikan kesempatan kepada masyarakat untuk menyelenggarakan pendidikan yang sesuai dengan kebutuhan setempat dengan mengandalkan kekuatan dan sumber daya yang digali dari masyarakat. Dalam khazanah bangsa kita, sudah sejak lama berkembang lembaga-lembaga pendidikan "tradisional" seperti pesantren yang menggunakan prinsip-prinsip ini. Lembagalembaga seperti itu tumbuh dan berkembang secara mandiri, tanpa banyak uluran tangan pemerintah. Penyelenggaraan pendidikan, menurut sistem ini, harus mengikutsertakan masyarakat karena masyarakatlah yang menjadi stake holders yang pertama dan utama dari proses pendidikan tersebut. Hal ini berarti proses pendidikan, tujuan pendidikan, dan sarana pendidikan, termasuk pula mutu pendidikan adalah merupakan tanggung jawab masyarakat setempat. Tidak mengherankan apabila dewasa ini suatu gerakan community-based management merupakan dasar dari pembangunan suatu masyarakat demokratis. Hal ini merupakan dampak dari diberlakukannya sistem desentralisasi pendidikan sebagai dampak dari otonomi daerah. Lihat Isjoni, Serial Manajemen: Arah PendidikanIndonesia Membangun Kemandirian Sekolah), (Pekanbaru: Unri Press, 2003), hlm. 33-34.

${ }^{10}$ Manajemen berbasis sekolah sebagai terjemahan dari School Based Management, adalah suatu pendekatan politik yang bertujuan untuk me-redasain pengelolaan sekolah dengan memberikan kekuasaan kepada Kepala Sekolah dan meningkatkan partisipasi masyarakat dalam upaya perbaikan kinerja sekolah yang mencakup guru, siswa, KS, orang tua siswa, dan masyarakat. Lihat Nanang Fattah, Konsep.. hlm.9.

${ }^{11}$ Dalam istilah bahasa Arab, kata "yayasan" disebut "mua'assasab". Lihat As'ad Muhammad al-Kalaly, Kamus Indonesia - Arab, (Jakarta: Bulan Bintang, 1987), hal. 595. Yang dimaksud dengan yayasan adalah badan hukum yang terdiri atas kekayaan yang dipisahkan dan diperuntukkan untuk mencapai tujuan tertentu di bidang sosial, keagamaan, dan kemanusiaan, yang tidak mempunyai anggota. Lihat Pasal 1 UU No. 16 Tabun 2001, (Yogyakarta: Media Pressindo, 2001), hlm. 4. Tujuan yayasan didirikan adalah untuk kegiatan sosial, keagamaan dan kemanusiaan yang tidak mencari keuntungan atau lembaga nomprofit/nirlaba. 
yang bergerak di bidang sosial, keagamaan dan kemanusiaan serta pendidikan, ${ }^{12}$ akan tetapi lemah di bidang administrasi dan keuangan. Pengaturan yayasan identik hanya atas dasar keinginan atau kesepakatan para pendirinya, oleh karena kesamaan visi yang selanjutnya diotentikkan dalam bentuk akta notaris pendiri yayasan. Ada juga yang didaftarkan pada pengadilan negeri. Cukup dengan akta notaris, sebuah yayasan sudah mempunyai status badan hukum.

Menyikapi perkembangan yayasan pendidikan yang demikian pesat yang bersifat tradisional, ${ }^{13}$ pemerintah Indonesia berupaya memberikan jaminan dan kepastian hokum dalam pelaksanaannya. Oleh karena itu, sejak tanggal 6 Agustus 2001, Indonesia telah memiliki suatu Undang-undang yang mengatur tentang Yayasan. Suatu perjalanan yang panjang, dimulai dari berbagai naskah akademik Undang-undang yang lahir silih berganti, pembicaraan yang panjang di DPR, ${ }^{14}$ akhirnya 45 (empat puluh lima) tahun setelah Belanda memiliki Undang-undang Yayasan, baru kini Indonesia memiliki Undang-undang

${ }^{12}$ Menurut Ki Hajar Dewantoro, proses terjadinya pendidikan dapat berlangsung di lingkungan keluarga, sekolah dan masyarakat. Berdasarkan pendapat tersebut, pendidik dapat dibedakan menjadi tiga macam, yaitu: 1) Orang tua sebagai pendidik di rumah, 2) Guru sebagai pendidik di sekolah, 3) Tokoh masyarakat sebagai pendidik di masyarakat. Diantara tiga pendidik ini harus bekerjasama, tenggang-menenggang, isi-mengisi dan tidak boleh bertentangan sehingga pendidikan integral dapat dicapai dengan harmonis. Lihat Madya Eko Susilo dan RB. Kasihadi, Dasar-dasar Pendidikan, (Semarang: Efhar Publising, 1988), hlm. 51. Selain itu, pendidikan merupakan kunci segala bentuk kemajuan hidup manusia sepanjang sejarah. Lihat Nur Uhbiyati, Ilmu Pendidikan Islam, (Bandung: Pustaka Setia, 1997), hlm. 10.

13 Seperti diketahui, sebelum lahirnya Undang-undang tentang Yayasan, pendirian Yayasan di Indonesia dilakukan berdasarkan kebiasaan dalam masyarakat, doktrin, dan yurisprudensi. Badan hukum Yayasan, di samping untuk tujuan sosial, keagamaan dan kemanusiaan, telah pula dipergunakan untuk tujuan-tujuan lain yang menyimpang dari tujuan semula penciptaan badan hukum ini. Yayasan telah dipergunakan untuk tujuan-tujuan yang bukan untuk tujuan sosial dan kemanusiaan, seperti untuk memperkaya diri sendiri atau pengurus Yayasan, menghindari pajak yang seharusnya dibayar, untuk menguasai suatu lembaga pendidikan untuk selama-lamanya, untuk menembus birokrasi, untuk memperoleh berbagai fasilitas dari negara atau penguasa, dan berbagai tujuan lain.

${ }^{14}$ Adapun pokok-pokok pikiran yang diajukan pemerintah dihadapan Rapat Paripurna DPR RI sewaktu UU tersebut masih berupa Draft/RUU Yayasan secara singkat antara lain sebagai berikut: Pertama, untuk memenuhi kebutuhan dan perkembangan hukum dalam masyarakat mengenai pengaturan tentang yayasan. Karena kenyataan dalam masyarakat yayasan tumbuh dan berkembang pesat dengan berbagai kegiatan, maksud dan tujuan, namun belum ada peraturan perundangan yang mengaturnya (pendirian yayasan selama ini hanya berdasarkan kebiasaan); Kedua, untuk menjamin kepastian dan ketertiban hukum serta fungsi yayasan sesuai maksud dan tujuannya berdasarkan prinsip keterbukaan dan akuntabilitas bagi masyarakat yang mendirikan yayasan; Ketiga, adanya fakta kecenderungan di dalam masyarakat, mendirikan yayasan dengan maksud untuk berlindung dibalik status badan hukum yayasan, untuk memperkaya diri para pendiri, pengurus dan pengawas, menghindari pajak yang dapat merugikan pihak ketiga, masyarakat dan negara. Lihat Syaeful Anwar, UU No. 16 Tabun 2001 Tentang Yayasan; Problem dan Solusi, Makalah Rakernas Lembaga Pendidikan Ma’arif NU Tahun 2002 di Malang Jawa Timur, hlm. 1. 
Al-Fikra: Jurnal Ilmiah Keislaman, Vol. 5, No. 1, Januari-Juni 2006

tentang Yayasan yaitu Undang-undang Republik Indonesia Nomor 16 Tahun 2001.

Dalam aplikasinya, ternyata UU tentang Yayasan reaksi dari kalangan pendiri/pengurus yayasan yang sudah ada dan lama berjalan. ${ }^{15}$ Reaksi yang kuat dan emosional muncul dari Organisasi Non-Pemerintah (Ornop) dan Lembaga Swadaya Masyarakat (LSM) terhadap Undang-undang Yayasan. ${ }^{16}$ Dengan demikian dapat dikatakan bahwa kebijakan pemerintah tentang Yayasan tersebut pada satu sisi memberikan solusi dan pada sisi lain menimbulkan permasalahan.

Adapun masalah-masalah yang dapat teratasi dengan adanya Undangundang Yayasan tersebut meliputi:

1) Badan Hukum Yayasan

Undang-undang Yayasan Nomor 16 Tahun 2001 mengakhiri perdebatan mengenai apakah Yayasan adalah suatu badan hokum atau bukan. Dalam undang-undang itu dijelaskan bahwa Yayasan adalah suatu badan hukum. ${ }^{17}$

2) Tujuan Sosial dan Kegiatan Usaha Yayasan

\footnotetext{
${ }^{15}$ Sebagai contoh Pasal 3 ayat (2) yang menyatakan bahwa "Yayasan tidak boleh membagikan hasil kegiatan usaha kepada pembina, pengurus dan pengawas".Lihat UU No. 16 , hlm. 5. Ketentuan dalam ayat ini sesuai dengan maksud dan tujuan yayasan yang bersifat sosial, keagamaan dan kemanusiaan, sehingga seseorang yang menjadi anggota pembina, pengurus dan pengawas yayasan harus bekerja secara sukarela tanpa menerima gaji, upah atau honor tetap. Lihat juga H. Muchsin, Permasalahan dan Solusi Akibat UU No. 16 Tabun 2001 Tentang Yayasan, Makalah Rakernas Lembaga Pendidikan Ma'arif NU Tahun 2002 di Malang Jawa Timur, hlm. 4.

${ }^{16}$ Chatamarrasyid Ais, Badan Hukum Yayasan: Suatu Analisis Mengenai Yayasan Sebagai Badan Hukum Sosial, (Bandung: Citra Aditya Bakti, 2002), hlm. 69. Ornop berpendapat bahwa Undang-undang Yayasan harus memiliki suatu paradigma yang terdiri dari prinsip-prinsip sebagai berikut: Pertama, prinsip Kebebasan Berorganisasi bagi masyarakat sipil tanpa adanya intervensi dari Negara/Pemerintah, baik dalam proses pembentukan sampai pembubaran; Kedua, prinsip Independensi merupakan kemandirian yang dimiliki oleh Yayasan dalam menentukan hal-hal yang berkaitan dengan pengaturan internal Yayasan (internal governance). Misalnya, dalam hal struktur organisasi, tanggung jawab, kewenangan dan fungsi organisasi; Ketiga, prinsip Transparansi yaitu memberikan kesempatan kepada masyarakat untuk dapat mengetahui dan mengakses seluruh kegiatan Yayasan secara jelas dalam upaya meningkatkan peran sertanya dalam melakukan pengawasan; Keempat, prinsip Akuntabilitas yaitu mengharuskan Yayasan mempertanggungjawabkan kegiatannya kepada masyarakat sesuai dengan tujuan Yayasan; Kelima, prinsip Nirlaba/Non-Profit Oriented yaitu bahwa Yayasan harus merupakan sutau lembaga Nirlaba. Oleh karena itu, tujuan pendirian Yayasan harus jelas pada bidang-bidang tertentu yang tidak berorientasi mendapatkan keuntungan, tetapi bidangbidang kemasyarakatan yang mengutamakan pelayanan publik.

${ }^{17}$ Lihat Pasal 1 butir 1 yang berbunyi: "Yayasan adalab badan bokum yang terdiri atas kekayaan yang dipisabkan dan diperuntukkan untuk mencapai tujuan tertentu di bidang sosial, keagamaan, dan kemanusiaan yang tidak mempunyai anggota".
} 
Al-Fikra: Jurnal Ilmiah Keislaman, Vol. 5, No. 1, Januari-Juni 2006

Ketentuan Pasal 1 butir 1 Undang-undang Yayasan Nomor 16 tahun 2001 dan pasal 3, 7, dan 8,18 menghapuskan kontroversi apakah Yayasan harus bertujuan sosial dan kemanusiaan, dan boleh melakukan kegiatan usaha atau mendirikan badan usaha yang dapat memperoleh laba. Yayasan boleh memperoleh laba dengan melakukan berbagai kegiatan usaha, sejauh laba yang diperoleh dipergunakan untuk tujuan idealitas, sosial dan kemanusiaan. Usaha yang memperoleh laba ini diperlukan agar Yayasan tidak bergantung selamanya pada bantan dan sumbangan pihak lain.

3) Siapa Pemilik Yayasan

Menurut Undang-undang Yayasan, bahwa Pendiri Yayasan bukanlah pemiliknya karena ia telah memisahkan kekayaannya untuk menjadi pemilik badan hukum Yayasan dan Pengurus juga bukanlah pemiliknya karena ia diangkat untuk mengurus organisasi Yayasan. ${ }^{19}$ Dengan demikian, menurut UU ini, Yayasan adalah milik masyarakat ${ }^{20}$ dan bukan milik para Pendiri/Pembina, Pengurus, dan atau Pengawas.

4) Keterbukaan Yayasan

Dalam hubungan ini, Undang-undang Yayasan nomor 16 Tahun 2001 mengharuskan Yayasan membuat Laporan Tahunan yang dapat diketahui oleh masyarakat dan dilakukan pemeriksaan terhadap Yayasan. ${ }^{21} \mathrm{Hal}$ ini

18Pasal 3 ayat 1 berbunyi: "Yayasan dapat melakukan kegiatan usaha untuk menunjang pencapaian maksud dan tujuannya dengan cara mendirikan badan usaba dan atau ikut serta dalam suatu badan usaha”. Dan Pasal 7 berbunyi: “(1) Yayasan dapat mendirikan badan usaba yang kegiatannya sesuai dengan maksud dan tujuan Yayasan; (2) Yayasan dapat melakukan penyertaan dalam berbagai bentuk badan usaha yang bersifat prospektif dengan ketentuan selurub penyertaan tersebut paling banyak $25 \%$ (dua pulub lima persen) dari selurub nilai kekayaan Yayasan; (3) Anggota Pembina, Pengurus, dan Pengawas Yayasan dilarang merangkeap sebagai Anggota Direksi atau Pengurus dan Dewan Komisaris atau Pengawas dari badan usaba sebagaimana dimaksud dalam ayat 1 dan ayat 2". Serta pasal 8 berbunyi: "Kegiatan usaba dari badan usaha sebagaimana dimaksud dalam Pasal 7 ayat 1 harus sesuai dengan maksud dan tujuan Yayasan serta tidak bertentangan dengan ketertiban umum, kesusilaan, dan atau peraturan perundang-undangan yang berlaku". Dan juga Penjelasan Pasal 8 yang berbunyi: "Kegiatan usaha dari badan usaha Yayasan mempunyai cakupan yang luas, termasuk antara lain hake asasi manusia, kesenian, olah raga, perlindungan konsumen, pendidikan, lingkungan bidup, kesehatan, dan ilmu pengetabuan".

${ }^{19}$ Lihat Pasal 3 ayat 2 yang berbunyi: "Yayasan tidak boleh membagikan hasil kegiatan usaha kepada Pembina, Pengurus, dan Pengawas". Dan Pasal 5 berbunyi: “Kekayaan Yayasan, baik berupa uang, barang, manpun kekayaan lain yang diperoleb Yayasan berdasarkan undang-undang ini, dilarang dialibkan atau dibagikan secara langsung atau tidak langsung kepada Pembina, Pengurus, Pengawas, Karyawan, atau pihak. lain yang mempunyai kepentingan terbadap Yayasan".

${ }^{20}$ Lihat Pasal 68 yang berbunyi: "(1) Kekayaan sisa hasil likuidasi diserabkan kepada Yayasan lain yang mempunyai maksud dan tujuan yang sama dengan Yayasan yang bubar; (2) Dalam hal sisa hasil likuidasi tidak diserabkan kepada Yayasan lain yang mempunyai maksud dan tujuan yang sama sebagaimana dimaksud dalam ayat 1, sisa kekayaan tersebut diserabkan kepada Negara dan penggunaannya dilakukan sesuai dengan maksud dan tujuan Yayasan tersebut".

${ }^{21}$ Lihat Pasal 52 yang berbunyi: “(1) Ikbtisar lapora tahunan Yayasan diumumkan pada papan pengumuman di kantor Yayasan; (2) Ikbtisar laporan tahunan sebagaimana dimaksud dalam ayat 1 wajib diumumkan dalam surat kabar harian berbahasa Indonesia bagi Yayasan yang: (a) memperoleh bantuan Negara, bantuan luar negeri, atau pibak. lain sebesar Rp. 500.000.000,- (lima ratus juta rupiah) 
Al-Fikra: Jurnal Ilmiah Keislaman, Vol. 5, No. 1, Januari-Juni 2006

berarti bahwa Yayasan harus bersikap terbuka dan tidak ada alasan untuk menyembunyikan atau merahasiakan masalah keuangan Yayasan, bahkan masalah kegiatan yang dilakukan oleh Yayasan.

Sedangkan masalah-masalah yang menjadi polemik dengan adanya Undang-undang Yayasan tersebut meliputi:

1) Apa yang dimaksud dengan Tujuan Sosial dan Kemanusiaan?

Undang-undang Yayasan tidak memberikan ketentuan apa yang dimaksud dengan tujuan sosial dan kemanusiaan, tetapi memberikan ketentuan mengenai kegiatan usaha yang dapat dilakukan oleh Yayasan. ${ }^{22}$ Ketidakadaan ketentuan apa yang dimaksud dengan tujuan sosial dan kemanusiaan, mengakibatkan tujuan tersebut harus dilihat dari kegiatan yang dilakukan.

2) Apa yang dimaksud dengan Kesalahan dan Kelalaian Organ Yayasan?

Pasal 39 dan 47 Undang-undang Yayasan ${ }^{23}$ memberikan kesan bahwa yayasan harus menganut doktrin "duty of skill and care". Artinya, bahwa yayasan harus senantiasa benar dan tidak boleh melakukan kesalahan. Tentu saja, penerapan doktrin ini tidaklah mudah dalam memilih orangorang yang akan didudukkan dalam Organ Yayasan. UU ini tidak memberikan ukuran/standar tentang kecakapan(skill) yang dibutuhkan untuk Organ Yayasan, dan juga batasan dari suatu perbuatan yang merupakan suatu kelalaian atau kealpaan. Sehingga pada akhirnya, penetapan keahlian dan atau kealpaan yang dilakukan oleh Organ Yayasan bersifat subyektif.

3) Itikad Baik

Pasal 35 dan 42 Undang-undang Yayasan ${ }^{24}$ menegaskan bahwa Organ yayasan dalam melaksanakan tugasnya harus beritikad baik. Artinya, dalam menjalankan tugasnya tidak boleh mempunyai kepentingan pribadi, atau

atau lebih; atau (b) mempunyai kekayaan di luar harta wakaf sebesar Rp. 20.000.000.000,- (dua puluh miliyar rupiah) atau lebih; (3) yayasan sebagaimana dimaksud dalam ayat 2 wajib diaudit oleh Akuntan Publik; dan seterusnya". Lihat juga Pasal 53, 54, 55 dan 56.

${ }^{22}$ Lihat Pasal 8 dan Penjelasannya.

${ }^{23}$ Pasal 39 yang berbunyi: “(1) Dalam hal kepailitan karena kesalahan atau kelalaian Pengurus dan kekayaan Yayasan tidak cukup untuk menutup kerugian akibat kepailitan tersebut, maka setiap Anggota Pengurus secara tanggung renteng bertanggung jawab atas kerugian tersebut; (2) Anggota Pengurus yang dapat membuktikan bahwa kepailitan bukan karena kesalahan atau kelalaiannya tidak bertanggung jawab secara tanggung renteng atas kerugian sebagaimana dimaksud dalam ayat 1". dan Pasal 47 berbunyi: "(1) Dalam hal kepailitan terjadi karena kesalahan atau kelalaian Pengawas dalam melakukan tugas pengawasan dan kekayaan Yayasan tidak cukup untuk menutup kerugian akibat kepailitan tersebut, setiap anggota Pengawas secara tanggung renteng bertanggung jawab atas kerugian tersebut; (2) Anggota Pengawas yang dapat membuktikan bahwa kepailitan bukan karena kesalahan atau kelalaiannya tidak bertanggung jawab secara tanggung renteng atas kerugian sebagaimana dimaksud dalam ayat 1".

${ }^{24}$ Pasal 35 ayat 2 berbunyi: "Setiap Pengurus menjalankan tugas dengan itikad baik dan penuh tanggung jawab untuk kepentingan dan tujuan Yayasan". Dan Pasal 42 berbunyi: "Pengawas wajib dengan itikad baik dan penuh tanggung jawab untuk kepentingan dan tujuan Yayasan". 
Al-Fikra: Jurnal Ilmiah Keislaman, Vol. 5, No. 1, Januari-Juni 2006

kepentingan pihak ketiga tanpa izin atau sepengetahuan Yayasan. Dalam aplikasinya, hal tersebut sering bersamaan sehingga sulit memisahkannya apakah seorang Pengurus Yayasan berbuat untuk kepentingan dirinya atau kepentingan Yayasan.

4) Peraturan Pemerintah

Beberapa pasal dalam Undang-undang yayasan tersebut membutuhkan pengaturan lebih lanjut dalam suatu Peraturan Pemerintah. ${ }^{25}$ Keterlambatan di dalam penerbitan berbagai Peraturan Pemerintah tersebut dapat menghambat perkembangan Yayasan, kepastian hukum, dan dapat menimbulkan berbagai permasalahan di kemudian hari.

5) Kontra Prestasi bagi Organ Yayasan

Suatu masalah yang sering dikemukakan, apakah seorang Pengurus dapat memperoleh gaji, upah, atau honor tetap Yayasan. Undang-undang Yayasan dengan tegas menyatakan bahwa Pengurus tidak boleh menerima gaji, upah atau honor tetap. ${ }^{26}$ Pasal ini perlu mendapat penafsiran bahwa jika Pengurus Yayasan tersebut adalah "pelaksana harian" atau dengan istilah lain "Pengurus Harian", 27 maka ia dibenarkan menerima gaji, ${ }^{28}$ karena ia memberikan seluruh waktunya untuk mengurus Yayasan sehingga ia tidak dapat lagi mengerjakan pekerjaan lainnya. Kalau tidak diberikan gaji, upah atau honor tetap, maka pemerintah yang mengeluarkan UU Yayasan ini dipandang zhalim. ${ }^{29}$

Jika diperhatikan secara seksama, pasal dan prinsip di atas akan memberikan kepastian hukum dan ketertiban dalam pelaksanaannya. Tetapi pada sisi lain jelas akan memancing reaksi yang keras dan emosional dari pihak yang terkait dengan yayasan dengan komentar bahwa mereka bukan "malaikat" yang tidak memerlukan makan, minum, sandang dan kebutuhan lainnya. Sehingga hal tersebut akan berdampak terhadap kelangsungan lembagalembaga pendidikan Islam yang ada di bawah naungan yayasan.

${ }^{25}$ Lihat Pasal 9, 14, 15, 24, 27, 61 dan 70.

26Lihat Pasal 3 ayat 2 yang berbunyi: "Yayasan tidak boleh membagikan hasil kegiatan usaha kepada Pembina, Pengurus, dan Pengawas". Serta Penjelasannya yang berbunyi: "Ketentuan dalam ayat ini sesuai dengan maksud dan tujuan Yayasan yang bersifat sosial, keagamaan, dan kemanusiaan, sehingga seseorang yang menjadi anggota Pembina, Pengurus, dan Pengawas Yayasan harus bekerja secara sukarela tanpa menerima gaji, upah, atau honor tetap".

${ }^{27}$ Lihat pasal 35 dan Penjelasannya.

${ }^{28}$ Lihat pasal 6 yang berbunyi: "Yayasan wajib membayar segala biaya atau ongkos yang dikeluarkan oleh organ Yayasan dalam rangka menjalankan tugas Yayasan".

${ }^{29}$ Chatamarrasyid Ais, Badan Hukum..., hlm. 39-53. 
Al-Fikra: Jurnal Ilmiah Keislaman, Vol. 5, No. 1, Januari-Juni 2006

\section{Eksistensi Madrasah Swasta}

Pada abad 21, madrasah ${ }^{30}$ di Indonesia kini berada di persimpangan jalan. Pada persimpangan jalan itu, madrasah harus dan dapat mengambil pilihan menempuh jalan tertentu, yang mengandung implikasi dan konsekuensi tertentu. Dengan kata lain, berhadapan dengan pilihan-pilihan sulit, yang tidak hanya berkaitan dengan persaingan madrasah dengan sekolah umum, tetapi juga dengan eksistensi madrasah itu sendiri di masa depan. Dilema dan pilihanpilihan sulit yang dihadapi madrasah banyak berkaitan dengan perkembangan internal madrasah, yang terutama muncul dari perkembangan pendidikan nasional secara keseluruhan. Undang-Undang Sistem Pendidikan Nasional (UUSPN) Tahun 2003, dan kemudian penerapan Kurikulum Berbasis Kompetensi (KBK) Tahun 2004, serta Undang-undang Otonomi Daerah yang diikuti dengan otonomisasi pendidikan, misalnya, merupakan landasan dasar kebijakan arah pengembangan pendidikan nasional yang jelas sangat mempengaruhi perkembangan eksistensi madrasah baik dari segi kelembagaan maupun substansi pendidikannya.

Madrasah sebagai institusi pendidikan tidak dapat mengelak dari kebijakan reformasi pendidikan yang bersifat desentralistik. Manajemen berbasis sekolah di lingkungan madrasah merupakan bentuk pengelolaan pendidikan yang ditandai dengan otonomi yang luas pada tingkat madrasah yang disertai semakin meningkatnya partisipasi masyarakat. Dengan kata lain, madrasah atau sekolah harus mampu melakukan improvisasi, yaitu keinginan elemen atau pihak sekolah untuk mencapai tingkatan tertentu dari tujuan yang ingin dicapai dalam proses pembelajaran, prestasi belajar, dan pengembangan masyarakat di sekitarnya. ${ }^{31}$

Dengan demikian dapat dikatakan bahwa dalam kaitannya dengan aspek kelembagaan, madrasah tidak dapat melepaskan diri dari faktor lingkungan pendidikan $^{32}$ yang menjadi salah satu penentu keberhasilan lembaga pendidikan itu sendiri dalam mencapai tujuan yang diinginkan. Lingkungan

30Kata "madrasah" dalam bahasa Arab adalah bentuk kata "keterangan tempat" (zharaf makan) dari akar kata "darasa". Secara harfiah "madrasab" diartikan sebagai tempat belajar para pelajar", atau "tempat untuk memberikan pelajaran. Lihat Mehdi Nakosteen, Kontribusi Islam atas Dunia Intelektual Barat: Deskripsi Analisis Abad Keemasan Islam, Edisi Indonesia (Surabaya: Risalah Gusti, 1996), hlm. 66. Dari akar kata "darasa" juga bisa diturunkan kata "midras" yang mempunyai arti "buku yang dipelajari" atau tempat belajar"; kata "al-midras" juga diartikan sebagai rumah untuk mempelajari kitab Taurat". Lihat Abu Luwis al-Yasu'i, al-Munjid Fi alLughah Wa al-Munjid Fi al-A'lam, Cet-23 (Beirut: Dar al-Masyriq, tt), hlm. 221.

${ }^{31}$ Kate Myers (ed), School Improvement in Practice, (London: Falmer Press, 1996), hlm. 11.

${ }^{32}$ Lingkungan pendidikan adalah segala sesuatu yang ada dan terjadi di sekeliling proses pendidikan itu berlangsung yang terdiri dari manusia, binatang, tumbuh-tumbuhan, dan benda mati. Keempat kelompok benda-benda lingkungan pendidikan itu ikut berperan dalam rangka usaha setiap siswa/mahasiswa mengembangkan dirinya. Tetapi manajemen pendidikan menaruh perhatiannya terutama kepada lingkungan yang berwujud manusia yaitu masyarakat. Lihat Made Pidarta, Manajemen Pendidikan Indonesia, (Jakarta: Rineka Cipta, 2004), hlm. 177. 
pendidikan yang dimaksud adalah masyarakat. Ada hubungan saling memberi dan saling menerima antara lembaga pendidikan dengan masyarakat sekitarnya. Madrasah merealisasikan apa yang dicita-citakan oleh warga masyarakat tentang pengembangan putra-putri mereka. Hampir tidak ada orang tua siswa yang mampu membina sendiri putra-putri mereka untuk dapat tumbuh dan berkembang secara total, integratif, dan optimal seperti yang dicita-citakan oleh bangsa Indonesia. Itulah sebabnya lembaga-lembaga pendidikan mengambil alih tugas ini. ${ }^{33}$ Lembaga pendidikan memberikan sesuatu yang sangat berharga kepada masyarakat. Sejalan dengan konsep di atas, pemerintah menyerukan bahwa pendidikan adalah tanggung jawab bersama antara pemerintah, orang tua dan masyarakat. Seruan ini mengisyaratkan bahwa lembaga pendidikan hendaknya tidak menutup diri, melainkan selalu mengadakan kontak hubungan dengan orang tua dan masyarakat sekitarnya sebagai penanggung jawab pendidikan.

Selama ini madrasah dikenal sebagai lembaga pendidikan tradisional Islam, baik yang berada di dalam maupun di luar kelembagaan pesantren. ${ }^{34}$ Madrasah, terlepas dari berbagai keterbatasan yang dihadapinya, harus diakui telah turut membina dan mengembangkan SDM kaum muslimin baik dalam bidang pengetahuan agama, maupun pengetahuan umum. ${ }^{35}$ Sebagai lembaga pendidikan Islam yang sebagian besarnya didirikan, diasuh, dibina dan

\footnotetext{
${ }^{33}$ Lembaga pendidikan sesungguhnya melaksanakan fungsi rangkap terhadap masyarakat yaitu memberikan layanan dan sebagai agen pembaru. Dikatakan fungsi layanan karena ia melayani kebutuhan-kebutuhan masyarakat berupa memberikan pendidikan dan pengajaran kepada putra-putri mereka. Sedangkan sebagai agen pembaharu karena ia harus selalu mengikutsertakan masyarakat dalam setiap pengambilan keputusan agar hasilnya lebih efektif. Selanjutnya dengan mengadakan kontak hubungan dengan masyarakat, akan memudahkan lembaga pendidikan itu menyesuaikan diri dengan situasi dan kondisi lingkunganya yang meliputi aspek politik, sosial dan budaya. Lembaga pendidikan lebih mudah menempatkan dirinya di masyarakat dalam arti dapat diterima sebagai bagian dari milik warga masyarakat serta dapat mengikuti arus dinamika masyarakat lingkungannya. Dengan demikian, lembaga pendidikan tersebut akan dapat bertahan lama dan mempunyai nama baik di hati masyarakat. Sebaliknya, lembaga pendidikan yang tidak mempunyai nama baik di masyarakat, pada akhirnya akan mati karena tidak ada lagi masyarakat yang simpatik dan mau mengantarkan anaknya ke lembaga pendidikan tersebut.

${ }^{34}$ Istilah pesantren berasal dari kata "santri", yang ditambahi awalan "pe" dan akhiran "an berarti tempat tinggal para santri. Lihat Badri Yatim, dkk., Sejarah Perkembangan Madrasah, (Jakarta: Ditjen Binbaga Islam Depag RI, 1999/200), hlm. 95. Lihat juga Nurcholis Madjid, Bilik-bilik Pesantren; Sebuah Potret Perjalanan, (Jakarta: Paramadina, 1997), hlm. 19

${ }^{35}$ Berkaitan dengan peningkatan antusiasme keagamaan yang dikemukakan di atas, dalam beberapa tahun terakhir ini, bahkan muncul dan berkembang minat di kalangan masyarakat muslim Indonesia untuk membangun madrasah unggulan dalam berbagai jenjang pendidikan. Tujuannya sudah jelas, yakni mencapai keunggulan (excellence) tidak hanya dalam bidang ilmu-ilmu keagamaan, tetapi juga dalam bidang ilmu-ilmu umum. Tugas yang dipikul madrasah pada akhirnya, adalah mewujudkan anak didik yang memiliki pengetahuan keislaman dan ilmu-ilmu lain; dan sekaligus dapat mengamalkan pengetahuan yang mereka miliki. Dengan begitu, mereka selanjutnya dapat tumbuh menjadi anggota masyarakat muslim Indonesia yang beriman dan bertaqwa kepada Allah swt.
} 
dikembangkan oleh kaum muslimin sendiri, madrasah dalam berbagai jenjang telah berperan besar dalam upaya-upaya meningkatkan kecerdasan dan, bahkan, martabat kaum muslimin. Seiring dengan peningkatan minat dan harapan masyarakat muslim umumnya terhadap madrasah, memandang tantangan-tantangan yang dihadapi bangsa dan dalam upaya untuk meningkatkan penguasaan sains-teknologi, kebijakan pendidikan nasional beberapa tahun terakhir ini mengharuskan madrasah, khususnya madrasah Aliyah, untuk juga lebih mengembangkan jurusan-jurusan umum, dan keterampilan. ${ }^{36}$

Selanjutnya, secara kuantitatif, jumlah madrasah kelihatannya meningkat; berbagai madrasah baru muncul di mana-mana, tidak hanya di Jawa, tetapi juga di Sumatera. Kondisi perkembangan madrasah dapat dilihat secara umum sebagai berikut:

1) Madrasah swasta lebih banyak dari madrasah negeri dan kebanyakan berada di pedesaan dengan latar belakang pendidikan sosial ekonomi orang tua yang rata-rata rendah.

2) Kemampuan pengelolaan (administrasi manajemen) belum seperti yang diharapkan dan tingkat pembiayaan pendidikan masih sangat memprihatinkan.

3) Tingkat pendidikan guru kebanyakan belum sepadan dengan persyaratan yang ditetapkan dan apabila dilihat dari kemampuan metodologi masih rendah, ditambah masih kurangnya tenaga kependidikan yang diperlukan.

4) Kemampuan mengajar guru madrasah kebanyakan masih menekankan pada pengenalan konsep yang bersifat kognitif dan belum menekankan pada prilaku beragama, etika sosial dan akhlak mulia.

Pada saat ini, di Indonesia, Madrasah Ibtidaiyah (MI) berjumlah 24.979 yang 24.370 atau 97,6 \% adalah swasta; Madrasah Tsanawiyah (MTs) berjumlah 8.001 yang 7.499 atau 92,8 \% adalah swasta; dan Madrasah Aliyah (MA) 2.928 yang 2.573 atau $88 \%$ adalah swasta. Apabila dilihat dari jumlah siswa, maka MI swasta yang berjumlah 3.008.868 atau 79,65\% dari selruh siswa MI yang berjumlah 3.777.734 siswa. MTs swasta mempunyai jumlah siswa 940.515 atau $75 \%$ dari seluruh siswa MTs yang berjumlah 1.241.977 siswa. Sementara MA swasta mempunyai jumlah siswa 268.169 atau 56,68 \%

36 Madrasah, dalam konteks ini, dipandang bukan lagi hanya merupakan lembaga transmisi ilmu-ilmu keagamaan Islam, tetapi juga tempat untuk menanamkan apresiasi, dan bahkan juga menaburkan bibit-bibit penguasaan, keterampilan dan keahlian dalam bidang sains-teknologi. Tujuan pokok yang dibayangkan dengan pengembangan madrasah dalam arah ini tidak hanya untuk menciptakan interaksi dan integrasi keilmuan yang lebih intens dan lebih padu antara "ilmu-ilmu agama" dengan ilmu-ilmu umum", termasuk yang berkaitan dengan sains-teknologi, tetapi juga akhirnya pada penguasaan terhadap sains-teknologi itu sendiri. Dalam kerangka ini, anak didik yang dihasilkan madrasah diharapkan tidak hanya mempunyai perspektif keilmuan yang integratif dan komprehensif-antara bidang ilmu-ilmu keagamaan dan ilmu-ilmu keduniaan-tetapi juga memiliki pengetahuan dan keahlian yang memadai untuk menghadapi masa industri dan pasca-industri. 
dari seluruh siswa MA yang berjumlah 473.111 siswa. Seluruh siswa madrasah (MI, MTs, dan MA) berjumlah 5.633.940 siswa adalah sebagai aset umat, bangsa dan Negara yang sangat besar dan tentunya juga berhak memperoleh pendidikan dengan sebaik-baiknya agar dapat melanjutkan pendidikan dan terjun ke dunia kerja dengan selayaknya pula. ${ }^{37}$

Yang menarik dari perkembangan kuantitatif ini adalah, pada sisi lain, munculnya gejala pertumbuhan madrasah-madrasah unggul dalam bidang materi, metode dan manajemen yang disajikannya. Masih dalam konteks perkembangan kuantitatif ini adalah terjadinya perpindahan murid-murid sekolah umum dalam berbagai jenjang ke madrasah di berbagai daerah. Sementara itu, perkembangan fisik bangunan madrasah juga mengalami kemajuan-kemajuan yang cukup observable. Banyak madrasah di berbagai tempat, apakah di kota atau di desa, mulai mempunyai gedung-gedung atau bangunan yang megah dan, lebih penting lagi, sehat dan kondusif sebagai tempat berlangsungnya proses pendidikan yang baik. Dengan demikian, citra yang pernah disandang madrasah yang memiliki bangunan seadanya, atau bahkan sudah hampir rubuh dan tidak sehat semakin memudar. Sehingga predikat madrasah sebagai lembaga pendidikan tradisional lambat laun akan hilang dengan sendirinya.

Fenomena ini mengindikasikan terjadinya peningkatan kemampuan swadaya dan swadana masyarakat muslim sebagai hasil dari kemajuan ekonomi yang dicapai oleh kaum muslim. Tentu saja semua itu tidak terlepas dari peran serta masyarakat muslim yang berada di sekitar madrasah yang terinternalisasi dalam sebuah wadah yang disebut "Yayasan". Korelasi antara yayasan dengan sekolah atau madrasah ${ }^{38}$ yaitu bahwa pada masa lalu, kebijakan pemerintah terhadap sekolah-sekolah atau madrasah swasta mengharuskan adanya yayasan yang menaunginya, seperti sekolah-sekolah yang berada di lingkungan Lembaga Pendidikan Ma'arif NU dengan Akte Notaris Joenoes E. Moegimon No. 103/1986, walaupun kondisi riil sekolah-sekolah tersebut pada awalnya didirikan secara perorangan atau keluarga.

Atas dasar itulah, di berbagai daerah termasuk Indonesia, bermunculan yayasan pendidikan yang menaungi lembaga-lembaga pendidikan Islam baik berbentuk sekolah maupun madrasah dengan nama, corak dan ragam sesuai dengan keinginan dan kemufakatan para pendirinya. Pada umumnya yayasan pendidikan Islam yang ada menaungi lembaga-lembaga pendidikan baik formal maupun nonformal seperti:

${ }^{37}$ Abdul Rachman Shaleh, Madrasah dan Pendidikan Anak Bangsa: Visi, Misi dan Aksi, (Jakarta: Raja Grafindo Persada, 2004), hlm. 23.

${ }^{38}$ Sebenarnya istilah "madrasab" ini sudah pernah dikenal pada awal-awal Islam. Hanya saja, bukan dalam arti lembaga formal dengan pembagian kelas dan kurikulum seperti sekarang ini, melainkan dalam arti sekedar tempat memberikan pelajaran dalam bentuk halaqah atau kelompok belajar yang mengambil tempat di sebahagian ruangan masjid. Lihat Zuharaini, dkk., Sejarah Pendidikan Islam, Cet.II, (Jakarta: Dirjen Binbaga Islam Depag RI, 1986), hlm. 71. 
Al-Fikra: Jurnal Ilmiah Keislaman, Vol. 5, No. 1, Januari-Juni 2006

1) Taman Kanak-kanak dan atau Raudhatul Athfal

2) Sekolah Dasar dan atau Madrasah Ibtidaiyyah

3) Sekolah Menengah Pertama dan atau Madrasah Tsanawiyah

4) Sekolah Menengah Umum dan atau Madrasah Aliyah

5) Perguruan Tinggi Agama Islam (PTAI) ${ }^{39}$

Berdasarkan data Statistik Pendidikan Agama dan Keagamaan Departemen Agama RI Tahun Pelajaran 2003-2004 Jumlah madrasah yang didirikan oleh yayasan pendidikan cukup banyak. ${ }^{40}$ Data ini setidaknya menunjukkan bahwa jumlah madrasah yang didirikan oleh yayasan pendidikan (dalam hal ini diistilahkan dengan madrasah swasta) lebih banyak dari jumlah madrasah yang didirikan oleh pemerintah (dalam hal ini diistilahkan dengan sebutan madrasah negeri), terutama di daerah-daerah pedesaan atau daerah terisolir. Hal ini mengindikasikan bahwa keberadaan yayasan pendidikan begitu dirasakan oleh masyarakat Islam di Indonesia. Dengan sekolah atau madrasah yang didirikan oleh yayasan pendidikan, masyarakat merasakan manfaat yang besar terutama menyangkut kebutuhan melanjutkan sekolah bagi putra-putri mereka. Apalagi secara realitas bahwa sekolah atau madrasah yang didirikan oleh pemerintah memiliki daya tampung yang terbatas, sehingga bagi anak yang tidak diterima pada sekolah negeri dapat melanjutkan ke sekolah swasta yang ada. Dengan demikian proses pendidikan mereka tidak terputus. Selain itu, bahwa dengan adanya sekolah atau madrasah swasta, terbuka peluang bagi tenaga pendidik dari berbagai disiplin ilmu baik alumni Fakultas Tarbiyah atau Fakultas Keguruan dan Ilmu Pendidikan (FKIP/IKIP) dapat mengabdikan ilmu mereka pada lembaga-lembaga tersebut.

Berdasarkan realitas sejarah, di awal kemerdekaan, madrasah memang terus hidup secara sederhana dan apa adanya karena tidak mendapat bantuan sepenuhnya dari pemerintah, yang ada hanya sebatas dorongan moral saja. Adanya perhatian pemerintah baru diwujudkan dengan keluarnya peraturan Menteri Agama No. 3 Tahun 1979 tentang pemberian bantuan kepada madrasah. Tetapi hal tersebut tidak terealisasikan sejak tahun 1965 dan di masa orde baru dijadikan sebagai bantuan lepas sampai sekarang. ${ }^{41}$ Selain itu juga, madrasah swasta hidup dan berkembang didukung oleh masyarakat yang sosial ekonominya rendah. Kebanyakan orang tua siswa madrasah adalah petani, hidup secara tradisional, berpendidikan rendah dan kebayakan hidup di daerah pedesaan dan pinggiran kota. Sarana dan prasarana madrasah sangat rendah dan tenaga guru kebanyakan dilatarbelakangi oleh semangat ibadah yang sangat

\footnotetext{
${ }^{39}$ Sebagai bahan perbandingan bahwa jenjang pendidikan formal yang ada di Indonesia hampir sama dengan jenjang pendidikan yang ada di Mesir, yaitu: Tingkat Ibtidaiyah (setingkat SD), tingkat I'dadiyah (setingkat SLTP), tingkat Tsanawiyah (setingkat SMU), tingkat Al-Jami'ah (setingkat Universtias). Lihat Mahmud Yunus, Perbandingan Pendidikan Modern di Negara Islam dan Intisari Pendidikan Barat, Cet. I., (Jakarta: Al-Hidayah, 1979), hlm. 34-68.

40Lihat Statistik Pendidikan Agama dan Keagamaan Tabun Pelajaran 2003-2004, (Jakarta: Ditjen Bagais Depag RI, 2004), hlm. 17.

${ }^{41}$ Abdul Rachman Shaleh, Madrasah, hlm. 22.
} 
tidak selektif terhadap persyaratan yang diperlukan. Keadaan demikian mengakibatkan madrasah sulit berkembang dan tidak mampu bersaing dengan sekolah lainnya.

Mengenai pendirian madrasah swasta didasarkan atas SK.Menteri Agama No. 5 Tahun 1977 yang pendirian pelaksanaannya dituangkan ke dalam Surat Keputusan Direktur Jenderal Bimbingan Masyarakat Islam No. Kep/D/69/77. Dalam hubungan ini, madrasah swasta diartikan sebagai lembaga pendidikan yang menjadikan mata pelajaran agama Islam sebagai mata pelajaran dasar yang diberikan sekurang-kurangnya $30 \%$ di samping mata pelajaran umum, dan diselenggarakan oleh organisasi, yayasan, badan atau perorangan sebagai pengurus atau pemiliknya. ${ }^{42}$ Berdasarkan petunjuk pelaksanaan (juklak) tersebut, dapat dipahami bahwa yayasan adalah salah satu lembaga penyelenggara pendidikan yang sah dalam mengelola madrasah swasta. Dalam perkembangan selanjutnya, ternyata yayasan pendidikan yang menaungi madrasah swasta berkembang cukup pesat.

Dengan demikian dapat dikatakan bahwa madrasah swasta memang mengemban tugas utama dalam hal pendidikan agama. Tetapi, posisinya sebagai subsistem dari sistem pendidikan nasional, di samping pesantren dan sekolah umum, lembaga madrasah tidak bias menghindar dari peraturan tentang pendidikan yang digariskan oleh pemerintah. Oleh karenanya, ketika pemerintah mencanangkan kurikulum baru itu, madrasah pun harus mengambilnya sebagai acuan dasar dalam kegiatan belajar mengajar.

Masalah lain yang sekarang ini sedang ramai dibicarakan di kalangan madrasah ialah bagaimana caranya madrasah meyambut era globalisasi tanpa kehilangan jati dirinya sebagai lembaga pendidikan Islam. Dalam konteks ini, madrasah harus mempersiapkan generasi mendatang dengan kemampuan, kompetensi dan skil sumber daya manusia yang tangguh. ${ }^{43}$ Oleh karena itu, berlakunya kurikulum 1994 yang mengajarkan pelajaran umum 100\% plus, mestinya dimengerti sebagai salah satu jalan yang akan membawa perubahan madrasah menjadi lembaga pendidikan yang punya nilai daya saing, baik dari segi kelembagaan maupun alumninya. Namun, tentu saja, hal ini harus disertai upaya peningkatan mutu pendidikan di madrasah dalam konteks pemberdayaan.

${ }^{42} \mathrm{Abdul}$ Rachman Shaleh, Madrasah, hal. 30. Organisasi-organisasi Islam yang bergerak di bidang pendidikan banyak mendirikan madrasah antara lain Muhammadiyah, Al-Irsyad, Mathlaul Anwar, Perhimpunan Umat Islam (PUI), Nahdlatul Ulama (NU), Persatuan Tarbiyah Islamiyah (PERTI), Al-Jam'iyatul Washliyah, dan lain-lain.

${ }^{43}$ Mochtar Buchori, pengamat pendidikan Islam, dalam tulisannya -Islamic Schools and Globalization - mengungkapkan bahwa tujuan lembaga pendidikan Islam untuk mempersiapkan sumber daya manusia di masa depan tidak mungkin ditolak. Termasuk madrasah. Tetapi, lulusan madrasah yang hanya mendapatkan pelajaran umum sebanyak $70 \%$, tidak mungkin bias bersaing dengan dengan lulusan sekolah umum yang mendapatkan pelajaran umum 100\%. Lihat The Jakarta Post, tanggal 2 April 1996. 
Sejauh ini, upaya pemberdayaan pemerintah (dalam hal ini Departemen Agama) teerhadap madrasah-madrasah yang berstatus negeri memang tidak menghadapi banyak persoalan, mengingat berbagai kelebihan yang dimiliki. Adanya fasilitas yang cukup, rasio guru-murid yang ideal, bantuan dari pemerintah dalam berbagai bentuk, dan kualitas anak didik yang standar, memungkinkan madrasah negeri berkembang sesuai dengan target pencapaian pendidikan. Tetapi bagi madrasah swasta, persoalannya menjadi lain. Upaya pemberdayaan terhadapnya seperti menelusuri jalan terjal. Berbagai langkah yang diambil untuk perbaikan mutu sekolah, penataan administrasi, peningkatan kemampuan guru, pelatihan kependidikan, dan lain-lain seperti tidak ada hasilnya. Kendala yang dihadapi sangat menumpuk, dari mulai membayar honor guru, membangun sarana pendidikan, sampai tenggang rasa dengan misi yayasan. Masalah lain yang dihadapi oleh madrasah swasta adalah berkaitan dengan kinerja para pengelola madrasah swasta baik pihak kepala sekolah maupun pihak Yayasan yang menaunginya. Pandangan umum tentang madrasah swasta boleh dikatakan beragam: guru-guru yang ala kadarnya, system administrasi yang belum professional, kesadaran property pemiliknya yang terlalu menentukan, input peserta dengan tingkat ekonomi yang rendah, dan lain-lain. Ibarat kata, madrasah swasta adalah lembaga pendidikan dengan segudang masalah.

Akan tetapi, sebenarnya, di balik kelemahan yang dijumpai tersebut, tersimpan potensi besar yang bias diberdayakan. Paling tidak dari segi otonomi kelembagaan. Karena status yang mandiri, madrasah swasta memiliki peluang yang lebih bebas untuk mengembangkan diri. Dari segi managerial, finansial dan fasilitas, pengelolaan madrasah swasta bias mengambil kebijakan-kebijakan strategis untuk menjaga kualitasnya, sehingga tidak perlu bergantung kepada pemerintah. Demikian juga, jika dilihat dari posisinya yang terintegrasi dengan masyarakat, sangat memungkinkan bagi madrasah swasta mengadakan upayaupaya pembaharuan atau penyesuaian kurikulum dalam konteks masyarakat setempat, dan dari sini terciptalah kondisi kegiatan belajar mengajar yang hidup.

Mengenai eksistensi madrasah swasta dengan lahirnya Undang-undang Yayasan tersebut dapat dijelaskan berikut ini: Tujuan membantu dunia pendidikan, pastilah termasuk di dalam tujuan sosial dan kemanusiaan. Tidaklah dipersoalkan dari mana suatu lembaga pendidikan menerima sumbangan, atau dengan kata lain sumber penghasilannya, tetapi yang penting adalah tujuannya. Persoalannya menjadi lain bila sekolah atau lembaga pendidikan itu diselenggarakan bagi keuntungan para pemiliknya. Tujuannya haruslah bagi promosi pendidikan untuk kepentingan umum dan bukan bagi kepentingan pribadi. Akan tetapi, kenyataan menunjukkan bahwa pemasukan "uang sekolah" tidak terkontrol. Yayasan yang memajukan pendidikan haruslah memajukan pendidikan masyarakat pada umumnya atau suatu bagian dari masyarakat yang tidak dipilih berdasarkan alasan-alasan hubungan pribadi, koneksi dengan penyumbang atau pengurusnya. Akan tetapi, mengenai 
hubungan pribadi (personal nexus) antara penyumbang dengan yang disumbang ini ada perbedaan pandangan. Namun, yang paling penting diperhatikan di sini adalah unsur kepentingan umum/manfaat publik (public benefit).

Kehadiran madrasah swasta yang berkualitas dalam berbagai jenis dan jenjang pendidikan sesungguhnya sangat diharapkan oleh berbagai pihak, terutama umat Islam. Bahkan, kini terasa sebagai kebutuhan yang mendesak, terutama bagi kalangan Muslim menengah yang secara kuantitatif terus meningkat belakangan ini. Hal ini mestinya menjadi acuan bagi para pengelola madrasah swasta dalam melakukan pemberdayaan. Banyak madrasah swasta yang berbeda, namun dikelola secara professional dan menempatkannya dalam konteks kemasyarakatan yang lebih luas, memperlihatkan perkembangan yang pesat. Keberadaannya pun semakin kokoh. ${ }^{44} \mathrm{Hal}$ ini disebabkan madrasah swasta lokasinya menyebar hingga ke pedesaan, uang sekolah yang relatif terjangkau oleh masyarakat kecil atau menengah ke bawah.

Dengan demikian dapat dikatakan bahwa kebijakan pemerintah dalam melahirkan Undang-undang Yayasan akan berdampak terhadap eksistensi madrasah swasta yang berada di bawah naungannya. Oleh karena keterbatasan penulis dalam mengungkapkan permasalahan tersebut, tentu saja perlu penelitian lebih lanjut.

\section{Kesimpulan}

Dari uraian yang dikemukakan di atas, dapat ditarik kesimpulan bahwa kebijakan pemerintah melahirkan Undang-undang Nomor 16 Tahun 2001 tentang Yayasan pada satu sisi memberikan kepastian hukum dan ketertiban dalam pelaksanaannya. Namun pada sisi lain, hal tersebut menimbulkan persoalan berupa reaksi yang keras dan emosional dari para pemilik dan pengelola Yayasan, karena UU tersebut terlalu mengikat gerak mereka selama ini. Reaksi yang keras dan emosional tersebut pada akhirnya akan berdampak terhadap kelangsungan lembaga pendidikan (dalam hal ini madrasah swasta) yang berada di bawah naungannya.

Dampak yang dirasakan oleh masyarakat dengan adanya UU Yayasan ini adalah kejelasan status hukum Yayasan itu dalam peraturan ketatanegaraan, sehingga diharapkan akan tertib dalam pelaksanaannya. Selain itu, peran masyarakat (dalam hal ini Pendiri Yayasan) menjadi terbatas sehingga pemilik Yayasan tidak boleh semena-mena dan sesuka hatinya dalam mengendalikan Yayasan yang milikinya.

Sedangkan dampak UU Yayasan terhadap madrasah swasta yang bernaung di bawahnya adalah kemajuan dalam berbagai aspeknya. Dengan UU

${ }^{44}$ Husni Rahim, sewaktu menjabat sebagai Direktur Perguruan Agama Islam Ditjen Bagais Depag RI, menyebut beberapa contoh madrasah swasta yang berhasil memberdayakan diri sesuai dengan cirri khasnya. Misalnya, MI Pembangunan Ciputat, Jakarta; MTs Muhammadiyah Lubuk Pakam, Medan; Madrasah Kayutanam, Indonesia. Madrasah-madrasah tersebut berkembang tanpa campur tangan dari pemerintah. 
Al-Fikra: Jurnal Ilmiah Keislaman, Vol. 5, No. 1, Januari-Juni 2006

tersebut, Yayasan menjadi lebih proporsional dalam memberikan hak-hak madrasah yang selama ini dikuasai oleh Pemilik Yayasan, terutama masalah keuangan. Namun pada sisi lain, UU tersebut menyebabkan para Pemilik Yayasan kurang bergairah dalam mengelola lembaga pendidikan yang dinaunginya, sehingga pada akhirnya akan menyebabkan kemunduran bagi lembaga pendidikan tersebut.

Dengan demikian dapat dikatakan bahwa secara tidak langsung Undangundang Yayasan tersebut akan berdampak terhadap kelangsungan madrasah swasta, khususnya di Indonesia dan umumnya di Indonesia.

\section{Bibliografi}

Ais, Chatamarrasyid, Badan Hukum Yayasan: Suatu Analisis Mengenai Yayasan Sebagai Badan Hukum Sosial, (Bandung: Citra Aditya Bakti)

Anwar, Syaeful, UU No. 16 Tahun 2001 Tentang Yayasan; Problem dan Solusi, Makalah Rakernas Lembaga Pendidikan Ma'arif NU Tahun 2002 di Malang Jawa Timur

Azizy, A. Qodri, Pengantar dalam Abdul Rachman Shaleh, Madrasah dan Pendidikan Anak Bangsa: Visi, Misi dan Aksi, (Jakarta: Raja Grafindo Persada, 2004)

Caldwell, Brian J. and Don K. Hayward, The Future of Schools; Lesson From The Reform of Public Education, (London: Falmer Press, 1998)

Departemen Agama, Statistik Pendidikan Agama dan Keagamaan Tabun Pelajaran 2003-2004, (Jakarta: Ditjen Bagais Depag RI, 2004)

Emira, Ibrahim Basuni, Tadris al-Ulum wa al-Tarbiyah al-Ilmiyyah, (Mesir: Dar alMa'arif, 1979)

Fattah, Nanang, Konsep Manajemen Berbasis Sekolah (MBS) Dan Dewan Sekolah, (Bandung: Pustaka Bani Quraisy, 2004)

Isjoni, Serial Manajemen: Arah PendidikanIndonesia (Membangun Kemandirian Sekolah), (Pekanbaru: Unri Press, 2003)

al-Kalaly, As'ad Muhammad, Kamus Indonesia - Arab, (Jakarta: Bulan Bintang, 1987)

Muchsin, H., Permasalahan dan Solusi Akibat UU No. 16 Tabun 2001 Tentang Yayasan, Makalah Rakernas Lembaga Pendidikan Ma'arif NU Tahun 2002 di Malang Jawa Timur.

Myers, Kate (ed), School Improvement in Practice, (London: Falmer Press, 1996

Nakosteen, Mehdi, Kontribusi Islam atas Dunia Intelektual Barat: Deskripsi Analisis Abad Keemasan Islam, Edisi Indonesia (Surabaya: Risalah Gusti, 1996) 
Al-Fikra: Jurnal Ilmiah Keislaman, Vol. 5, No. 1, Januari-Juni 2006

Noor, Syakirman M., Menuju Masyarakat Madani Sebuab Pengantar dalam Indonesia Baru Menuju Masyarakat Madani (Padang: Baitul Hikmah Press, 2000)

Pidarta, Made, Manajemen Pendidikan Indonesia, Jakarta: Rineka Cipta, 2004

Shaleh, Abdul Rachman, Madrasah dan Pendidikan Anak Bangsa: Visi, Misi dan Aksi, (Jakarta: Raja Grafindo Persada, 2004)

Susilo dan RB. Kasihadi, Dasar-dasar Pendidikan, (Semarang: Efhar Publising, 1988)

The Jakarta Post, tanggal 2 April 1996.

Undang-Undang No. 16 Tabun 2001, Pasal 1, (Yogyakarta: Media Pressindo, 2001)

Uhbiyati, Nur, Ilmu Pendidikan Islam, (Bandung: Pustaka Setia, 1997

Vincent, Carol, Parents and Teachers Power and Participation, (London: Falmer Press, 1996)

al-Yasu'i, Abu Luwis, al-Munjid Fi al-Lughah Wa al-Munjid Fi al-A'lam, Cet-23 (Beirut: Dar al-Masyriq, tt)

Yatim, Badri, dkk., Sejarah Perkembangan Madrasah, Jakarta: Ditjen Binbaga Islam Depag RI, 1999/200), hal. 95. Lihat juga Nurcholis Madjid, Bilik-bilik Pesantren; Sebuah Potret Perjalanan, Jakarta: Paramadina, 1997)

Yunus, Mahmud, Perbandingan Pendidikan Modern di Negara Islam dan Intisari Pendidikan Barat, Cet. I., (Jakarta: Al-Hidayah, 1979)

Zuharaini, dkk., Sejarah Pendidikan Islam, Cet.II, (Jakarta: Dirjen Binbaga Islam Depag RI, 1986) 